\title{
Nuclear Receptor Subfamily 2 Group C Member 2
}

National Cancer Institute

\section{Source}

National Cancer Institute. Nuclear Receptor Subfamily 2 Group C Member 2. NCI

Thesaurus. Code C106599.

Nuclear receptor subfamily 2 group C member 2 (596 aa, $\sim 65 \mathrm{kDa}$ ) is encoded by the human NR2C2 gene. This protein is involved in both hormone binding and transcriptional regulation. 